Shakespeare et les arts de la table

\title{
Failures of Eating in The Merchant of Venice
}

\author{
David B. Goldstein
}

\section{(2) OpenEdition \\ Journals}

\section{Electronic version}

URL: http://journals.openedition.org/shakespeare/1702

DOI: 10.4000/shakespeare.1702

ISSN: 2271-6424

\section{Publisher}

Société Française Shakespeare

\section{Printed version}

Date of publication: 3 March 2012

Number of pages: 31-46

ISBN: 2-9521475-8-2

\section{Electronic reference}

David B. Goldstein, «Failures of Eating in The Merchant of Venice ». Actes des congrès de la Société française Shakespeare [Online], 29 | 2012, Online since 03 March 2012, connection on 01 May 2019. URL : http://journals.openedition.org/shakespeare/1702 ; DOI : 10.4000/shakespeare.1702 


\section{Shakespeare et les arts de la table}

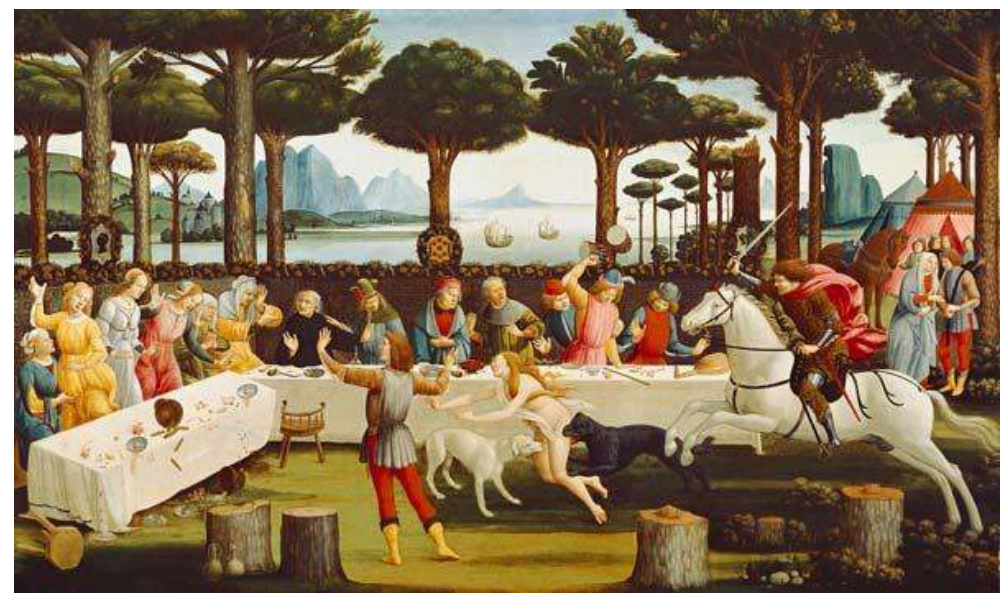

actes du Congrès

organisé par la

SOCIÉTÉ FRANÇAISE SHAKESPEARE

les 17, 18 et 19 mars 2011

textes réunis par

Christophe HAUSERMANN

et

Pierre KAPITANIAK

sous la direction de

Dominique GoY-BLANQUET 
COUVERTURE :

Botticelli, Banquet dans la forêt de pins,

Troisième tableau de la série

"L'histoire de Nastagio degli Onesti » inspiré d'une nouvelle du Décaméron de Boccace Musée du Prado, Madrid

conception graphique et logo

Pierre Kapitaniak

mise en page et corrections

Christophe Hausermann

Pierre Kapitaniak

(C) 2011 Société Française Shakespeare Institut du Monde Anglophone Université de Paris III - Sorbonne Nouvelle 5 rue de l'École de Médecine 75006 Paris

www.societefrancaiseshakespeare.org

Tous droits de traduction, de reproduction et d'adaptation réservés pour tous les pays 


\title{
FAILURES OF EATING IN THE MERCHANT OF VENICE
}

\author{
David B. GOLDSTEIN
}

\begin{abstract}
The Merchant of Venice contains numerous references to meals. Yet, strikingly, there is virtually no staged eating in the play. Food does not nourish, or it does so at such cost that it is hardly worth the trouble. Nevertheless, people eat, as they must: here, as elsewhere in Shakespeare, the body and its terrible appetites demand to be assuaged. The play is utterly permeated with eating, from the opening image of the wind cooling the "broth" of the sea, to the metaphor of manna raining from the proverbial skies of Portia's generosity. The whole world of this play is potentially edible, at once offered to some and withheld to others. Of course, this means that its characters are also potentially edible, and therefore vulnerable. Shakespeare creates a work in which at issue is a "pound of flesh," interchangeable with that of mutton, goat, pork, or another human. The Merchant of Venice is a play about the reduction of humanity to matter, and about the potential for that matter to become consumed. It is about how eating unites and, more frequently, destroys.
\end{abstract}

The Merchant of Venice contient de nombreuses références aux repas. Cependant, il est frappant de constater qu'aucun n'est mis en scène dans la pièce. La nourriture ne nourrit pas, ou elle demande pour cela un tel effort qu'il en devient dissuasif. Néanmoins, les gens doivent se sustenter. Dans cette pièce comme dans tout le corpus shakespearien, le corps exige que l'on calme son terrible appétit. La nourriture occupe une place centrale dans la pièce, qui s'ouvre sur l'image du vent refroidissant la « soupe » de la mer et qui offre plus loin une métaphore comparant la générosité de Portia à une manne tombée du ciel. Le monde décrit dans la pièce semble potentiellement comestible, il est offert à certains mais refusé à d'autres. Les personnages semblent également comestibles, et donc vulnérables. Shakespeare crée une œuvre dans laquelle il interroge l'interchangeabilité d'une « livre de chair » et d'une livre de mouton, de chèvre, de porc, ou de tout être humain. The Merchant of Venice est une pièce sur la réduction de l'humanité à une simple matière et sur le potentiel de cette matière d'être consommée. Elle démontre comment le fait de manger peut unir, ou plus fréquemment comment il peut mener à la destruction.

$I$.

$\mathrm{W}$

hat does it mean to eat in The Merchant of Venice? The play rarely comes up in discussions of food in Shakespeare ${ }^{1}-$ it has neither the overt, plot-driving cannibalism of Titus Andronicus, nor the picturesque pippins and cheese of The Merry Wives of Windsor, nor Hamlet's metaphysical meditations upon kings going on progress through the guts of beggars. Yet the Merchant is utterly permeated with food imagery, from the opening image of

\footnotetext{
${ }^{1}$ Exceptions include critics who discuss the implications of the play's cannibalistic imagery; see especially Leslie A. Fiedler, The Stranger in Shakespeare, New York, Stein and Day, 1972, p. 109-111; James Shapiro, Shakespeare and the Jews, New York, Columbia University Press, 1996, p. 109-110; Kim Hall, "Guess Who's Coming to Dinner? Colonization and Miscegenation in The Merchant of Venice," Renaissance Drama 23, 1992, p. 93-95. On Jewish cannibalism in Elizabethan drama, see Jacob Lopes Cardozo, The Contemporary Jew in the Elizabethan Drama, Amsterdam, H.J. Paris, 1925.
} 
Salerio blowing on the "broth" of his soup, to the closing metaphor of manna raining from the proverbial skies of Portia's generosity. People constantly talk about how they are going to eat, have eaten, wish they could eat, or wish they hadn't eaten - they do everything except actually eat, since not one of the play's meals is staged. Like Troilus and Cressida and Timon of Athens, but unlike As You Like It or Pericles, food in this play does not nourish, or it does so at such cost that it is hardly worth the trouble. Eating is almost always invoked aggressively, with bared teeth. Rather than communicate a sense of abundance, this gastronomic plethora infuses the play with a sense of edibility and mortality. The whole world of this play is potentially consumable, at once offered to some and withheld to others. Between Portia's spidery clutches and Shylock's knife hangs suspended a world of eaters and eaten. Eating in The Merchant becomes a central material site at which the play's fundamental conflicts are rehearsed.

\section{II.}

When we first meet Shylock, he and Bassanio are discussing the terms of Antonio's bond. After a few lines of dialogue, Shylock asks to speak with Antonio, and Bassanio replies, "If it please you to dine with us." Shylock famously responds:
Yes - to smell pork, to eat of the habitation which your prophet the Nazarite conjured the devil into? I will buy with you, sell with you, talk with you, walk with you, and so following. But I will not eat with you, drink with you, nor pray with you. What news on the Rialto? Who is he comes here? (I.iii.28-33) ${ }^{2}$

"I will not eat with you": Shylock will engage in trade and mercantile exchange, but, as an observant Jew, he draws the line at breaking bread with Christians. To do so would, as Shakespeare and much of his audience knew, compromise Shylock's observance of the kosher laws, the laws of kashrut. ${ }^{3}$ The first part of Shylock's rejoinder, however, has not received much commentary from critics, and provides us with a

\footnotetext{
${ }^{2}$ All line references are to William Shakespeare, The Merchant of Venice: Authoritative Text, Sources and Contexts, Criticism, Rewritings and Appropriations, ed. Leah S. Marcus, Norton critical, New York, W.W. Norton, 2005.

3 For a discussion of the relationship between kashrut and pork in the play, see David B. Goldstein, "The Price of Pork: Jews, Scots, and Pigs in The Merchant of Venice," forthcoming.
} 
window into the complexity of the play's attitudes toward eating. "To smell pork" - why is it the first thing we learn about Shylock, besides the fact that he practices usury, that he doesn't eat pigs? The line refers, as editors have noted, to a tale told three times in the New Testament gospels. ${ }^{4}$ Although Matthew, Mark, and Luke all tell slightly different versions of the story, the narrative runs generally as follows: Jesus comes upon a man possessed by spirits. When he threatens to exorcise them and banish them to the gates of Hell, they beg instead to be ejected into a herd of swine grazing nearby. Jesus does so, thus causing the hogs to go berserk; they run down the hill to a body of water and drown themselves. The man is cured but the city's inhabitants, frightened by the event, beg Jesus to leave the region, which he does. This story was extremely popular in the Middle Ages; according to Jacques Verroust and his colleagues, "Time and again it was revisited and commented upon by preachers and theologians, and it helped create the close association of pork with Satan."5

What to a modern audience may seem simply Shylock's roundabout way of saying that he keeps kosher, was for earlier readers a shocking, even sacrilegious formulation. Samuel Johnson, for example, found the line offensive enough to excise it silently from his edition. Why? First of all, it puts a story from Christian scripture into the mouth of a Jew. Shakespeare could have Shylock illustrate his distaste for pigs by quoting the Leviticus prohibitions. Instead, Shylock quotes the New Testament, and in so doing wields the Christian Bible against the Christians - setting the stage for the trial scene, in which the Jewish Scriptures will be wielded against the Jews. ${ }^{6}$ The Biblical

\footnotetext{
${ }^{4}$ Matthew 8:28-34, Mark 5:1-20, and Luke 8:26-39. For a notation of the passage's sources, and for some of the reasons behind Shylock's use of Nazarite instead of Nazarene, see Naseeb Shaheen, Biblical References in Shakespeare's Plays, Newark, DE, University of Delaware Press, 1999, p. 158.

5 "Il a été repris et commenté maintes et maintes fois par les prédicateurs et par les théologiens, et a contribué à faire du porc l'un des attributs préférés de Satan.” Jacques Verroust, Michel Pastoureau, and Raymond Buren, Le Cochon. Histoire symbolique et cuisine du porc, Paris, Le sang de la Terre, 1987, p. 52, translation mine.

${ }^{6}$ I refer here of course to Portia's "The quality of mercy is not strained" speech. One group of critics, generally called "supersessionist" (though in the present context I am tempted to call them "suppersessionist"), the most prominent among them being Nevill Coghill, Barbara Lewalski, John Coolidge, and Lawrence Danson, argue that the play stages a conflict between the "Old" Jewish law of Justice and the "New" Christian law of mercy, and that the New law triumphs in the trial scene. I strongly disagree with this argument, as I hope much of the material of this paper will make clear. Although I have not the space to refute the allegorical argument directly, others have already done so, especially Janet Adelman, to whose reading of the interactions between Judaism and Christianity in the play
} 
story implies that pigs are foul creatures, the right sort of vessel for the devil's habitation. Indeed, the Geneva Bible commentary glosses the detail that the town asks Jesus to depart after his miracle by comparing the degradation of pigs to the moral turpitude of the frightened inhabitants: "Where men live as swine, there Christ does not abide, but demons." Shylock could say, "We don't eat pigs, even if they are fine for you." Instead, he suggests, "See how unclean pigs are? Even your own holy writ agrees. How can you eat them yourselves?"

Shylock's insult, however, is worse than this. The swine of the gospel story are not just depraved by association with demons; they are literally inhabited by them. With its indecently dangling preposition, Shylock's rhetorical construction - "to eat of the habitation which your prophet the Nazarite conjured the devil into!" - emphasizes the action of putting the devil into hogs, but says nothing about removing it. ${ }^{7}$ The implication is not only that pigs are disgusting creatures, fit only for devils, but that in eating pork, one eats a devil embedded within. The adage "You are what you eat" may be a modern phrase, having originated with the nineteenth-century French food writer JeanAnthelme Brillat-Savarin, but it was generally taken far more seriously and literally in the Renaissance than it is today. Numerous authorities believed that diet could effect profound changes, some of them irrevocable, upon the physical and spiritual makeup of the eater. ${ }^{8}$ Thus Shylock's insult operates metonymically: pork, the habitation of the devil, transfers its devilry to those who eat it. Those who allow pork

I am greatly indebted. Regardless of the merits of the allegorical reading, the point I wish to underline-I do not think it has been noted-is that Shylock here employs precisely the same exegetical technique against Bassanio and Antonio that Portia will employ against Shylock at the climax of the play, when she marshals Ecclesiastes, Deuteronomy, Isaiah, and Proverbs, among many other Old Testament sources, to make the case for Christian mercy over Jewish justice. See Nevill Coghill, "The Basis of Shakespearian Comedy," Essays and Studies 3, 1950, p. 21-23; Barbara K. Lewalski, "Biblical Allusion and Allegory in The Merchant of Venice", Shakespeare Quarterly 13, no. 3 (Summer 1962), p. 327-343; John S. Coolidge, "Law and Love in The Merchant of Venice," Shakespeare Quarterly 27, no. 3 (Summer 1976), p. 243-263; Lawrence Danson, "The Harmonies of The Merchant of Venice", Yale University Press, 1978); Janet Adelman, Blood Relations: Christian and Jew in The Merchant of Venice, Chicago, University of Chicago Press, 2008. On the Old Testament roots of Portia's speech, see Shaheen, Biblical References, p. 180-182.

7 The line's peculiar syntax may also be meant to evoke the bawdy story, whose best known avatar is the tenth tale of the third day of Boccaccio's Decameron, of "putting the devil back into hell." This would of course constitute a further insult.

8 On the Galenic science that underpins much of this thinking, see, e.g., Ken Albala, Eating Right in the Renaissance, Berkeley, Los Angeles/London, University of California Press, 2002. 
into their bodies allow the devil in as well; to eat pig is to eat the devil himself. If pork was the "habitation" of the devil in the gospels, the Christian body becomes the "habitation" of both swine and Satan according to Shylock's cosmology. Shylock's pig functions as an inverted Eucharist - Christians think they are eating God, when in fact (to paraphrase Milton) they know not that they are eating the devil.

When, a few lines later, Antonio jeers that "The devil can cite Scripture for his purpose" (I.iii.96), the stakes of Shylock's comment become clear. Throughout the Middle Ages and the Renaissance, Jews were accused of associating with the devil or of being inhabited by devils. ${ }^{9}$ To put the devil in pigs is to put the devil in Christians, thus resisting, reversing, or deflating the same accusation that had for centuries been leveled against the Jews. Shakespeare makes sure that we understand the connection by postponing any comparison between Jews and devils until after Shylock's line, and then steadily intensifying such rhetoric throughout the drama. The word "devil" occurs fourteen times in the play, nine of them in relation to Shylock, and all of those occur after his use of the term in reference to "the Nazarite."

Little has been written about pork in the play, but as this brief exploration of Shylock's line demonstrates, it is an extremely fraught foodstuff. It is the food that keeps Christians and Jews from sitting down together at the same table to dine, a sticking point between the two faiths. But pork also serves as a marker for a more general problem - the problem of meals in the play. Not just Shylock, but all characters find sitting down to eat together a problematic act. If we look closely at how characters eat or don't eat together in the play, we find Shakespeare working out a whole set of issues about what it means to be in relation with other people. To provide hospitality, to share food,

\footnotetext{
${ }^{9}$ Here I part company with Shapiro, who takes the mystifying stance that "by the late sixteenth century the widespread medieval identification of Jews and the devil had virtually disappeared in England.” The Merchant of Venice seems its own refutation of this idea. Shapiro cites Joshua Trachtenberg in support of this position, but Trachtenberg's book, published during the Second World War, makes the opposite argument. His magisterial survey traces the long medieval association of Jews with devils and implies, though his book ends with Luther (who also associated Jews with Satan), that the Christian West has never stopped viewing the Jew as "the devil's own." Shapiro, Shakespeare and the Jews, p. 33; Joshua Trachtenberg, The Devil and the Jews: The Medieval Conception of the Jew and Its Relation to Modern Antisemitism, New Haven/London, Yale University Press/ Oxford University Press, 1943, p. 217. See also Derek Cohen, "Shylock and the Idea of the Jew," in The Merchant of Venice: Authoritative Text, Sources and Contexts, Criticism, Rewritings and Appropriations, Norton critical, New York, W.W. Norton, 2005, p. 196197.
} 
to acknowledge the needs and wants of others, to address or ignore those needs, to build and destroy community - in sum, to recognize and respond to otherness itself - is perhaps the play's great concern. But its ideas of eating together are anything but optimistic.

\section{III.}

The connection between eating and community is ancient and formative: biological, evolutionary, archaeological, and anthropological research shows that the act of eating together provides a fundamental architecture for human sociality. The general term for these communal aspects of eating, in the Renaissance as now, is commensality. The word, widely used in the social and biological sciences but rarely in the humanities, emerged in the early fifteenth century, having been borrowed from French and derived ultimately from the medieval Latin term commensalism. From the first, "commensal" meant both the act of eating at the same table, and a member of the company who did so. The term "commensality" - from the Latin com + mensa, "with the table," first appeared in a 1611 French-English dictionary, defined as "a continuall feeding together at one table." ${ }^{10}$ Almost immediately, commensality came to denote metaphorical and spiritual acts of eating as well as literal ones. A feeding together always gestures toward a "continuall" feeding; commensality overflows its temporal and spatial bounds, creating ineffable but no less real group identifications in the wider world, especially the theological and spiritual realms.

Commensality - eating together - means something different from conviviality, the enjoyment of another's company. To form a group means to exclude others from it; to share food means also to keep others away from the table of power. "It is disingenuous," writes Mary Douglas, "to pretend that food is not one of the media of social exclusion." ${ }^{11}$ Commensality has a dark side - namely the cultural mechanism that divides the eaters from those who starve, those we love from those we ignore or destroy. The exclusions that commensality creates, the costs of its obligations, and the negative ramifications of its

\footnotetext{
${ }^{10}$ See "commensality" in The Oxford English Dictionary.

${ }^{11}$ Mary Douglas, "Standard Social Uses of Food: Introduction," in Food in the Social Order: Studies of Food and Festivities in Three American Communities, ed. Mary Douglas, New York, Russell Sage Foundation, 1984, p. 36.
} 
inclusions, are very much at issue in the Renaissance. The language and practices of eating help define, exclude, and do violence to marginalized groups - to devour them, spit them out, or toss them aside. Such commensal violence is never more on display than in The Merchant of Venice.

\section{$I V$.}

Let's get back to Shylock's first speech, now focusing on the last part:

I will buy with you, sell with you, talk with you, walk with you, and so following; but I will not eat with you, drink with you, nor pray with you. What news on the Rialto? Who is he comes here? (I.iii.30-33)

The occasion for Shylock's outburst is that Bassanio has just invited him over for dinner (at either Bassanio's or Antonio's, it is not clear) to talk business. This is a dinner that we as the audience are already anticipating, since Shakespeare has Lorenzo mention it twice in the first scene of the play - Gratiano too gets into the act, telling Antonio that he'll keep trying to cheer him up after he's filled his belly. It's as if Shakespeare were setting up a grand banquet at which all the friendship and animosity of the play will soon converge as in Timon of Athens or Macbeth. But Shylock scorns the invitation as if he's been handed a spider. He will not eat in a Christian house, any more than he will pray in a church. Whether the kosher laws are designed to keep Jews from mixing with Christians at the dinner table or whether this is an effect of their application (scholars have argued the point for centuries), here it is all one. Shylock's ritual practice makes the very thought of sitting down at a Christian table as abhorrent and impossible as eating pork.

The problem, of course, is that he promptly decides to do just that. The very next time he enters, in Act II scene v, it is to go to dinner with Bassanio and Antonio:

I am bid forth to supper, Jessica.

There are my keys; but wherefore should I go?

I am not bid for love - they flatter me -

But yet I'll go in hate to feed upon

The prodigal Christian. 
What is going on here? How can Shylock's insistence have melted so easily into acquiescence? His proffered reason for accepting the invitation - which comes down essentially to "hey, free food!" - is bizarre. The image of a parasite "feeding upon" his host fits the economic resonances of the play, and especially of the usurious bloodsucker. But in order to make the image work, we have to ignore Shylock's protestations of a few minutes earlier that he won't eat a mouthful of Christian food. There is no particular reason for him to join the Christians for dinner: the bond has been written and sealed, so there is not much to negotiate, and those negotiations could easily transpire in a less highly-charged locale. The best explanation for his departure is to fulfill a plot point - to make sure that he is out of the house when Jessica escapes into the arms of Lorenzo (who leaves the very same dinner to come snatch her). Shylock's supper with the Christians - so instrumental for Jessica's plotline, so ludicrous for Shylock's character - alerts us to the ways in which eating is shortcircuited in this play.

If we need further evidence of the complexities of commensality for Shylock's character, we may look to Act III scene i, at the moment when Shylock urges Antonio to "look to his bond." Shylock, still raging over Jessica's departure, encounters Solanio and Salerio on the streets of Venice. They tease him about Jessica, claiming that there is "more difference between your bloods than there is between red wine and Rhenish," thus suggesting that they are both edible - Jessica is a long cool drink, Shylock a tannic affront to digestion. They amplify the trope by calling Shylock "old carrion" in a pun at once sexual and culinary, rendering him an inhuman creature of rank edibility. Shylock retorts vaguely that Antonio had better "look to his bond." Salerio, perhaps willfully underestimating Shylock's hatred, expresses disbelief:

SALERIO. Why, I am sure, if he forfeit, thou wilt not take his flesh: what's that good for?

SHYLOCK. To bait fish withal. If it will feed nothing else, it will feed my revenge. He hath disgraced me, and hinder'd me half a million... and what's his reason? I am a Jew. Hath not a Jew eyes? Hath not a Jew hands, organs, dimensions, senses, affections, passions - fed with the same food, hurt with the same weapons, subject to the same diseases, healed by the same means, warmed and cooled by the same winter and summer, as a Christian is? If you prick us do we not bleed? if you tickle us do we not laugh? if you poison us do we not die, and if you wrong us, shall we not revenge? If we are like you in the rest, we will resemble you in that.... The villainy you teach 
me I will execute, and it shall go hard but I will better the instruction.
(III.i.42-60)

Readers of the play have made this its most famous speech, perhaps because of the endlessly fascinating tension at its core. Shylock's rhetoric appeals to a common humanity, in which there are no others but only selves, in which all strangers have become brothers. The tyranny of small differences is upended by a paradise of no difference. Jews and Christians have eyes, hands, organs, they are fed with the same food. They should be treated equally.

But hold on. Fed with the same food? Did not Shylock begin his first scene by asserting in fervent terms that he was emphatically not fed with the same food as Christians were, and that this marked an impregnable divide between the two religions? Is it not problematic that at the moment of Shylock's assertion of identity between Christian and Jew, he flatly contradicts his prior assertion of difference?

Most readers see at least two ways to read the gap between "I will not eat with you" and "fed with the same food," and end up either choosing one or the other, or trying to keep both simultaneously in play. One way is to read the passage skeptically - to see it as a rhetorical, even hypocritical ploy whose goal is to justify the terms of Shylock's revenge. In this reading, Shylock is simply lying. He gestures toward kinship and community in order to manipulate his listeners. A second reading would be to assign different meanings to the apparently contradictory phrases. "I will not eat with you" is about food narrowly defined, about the question of what specific foods, like pork, are allowed to Christians as opposed to Jews. "Fed with the same food," on the other hand, is about the fact that we all need the same set of nutrients to survive, we all need to eat, and if we don't, we all die. In this reading, eating takes on the resonance of universal sustenance under the signs of God and biology, the fact of feeding that transcends religious disputes.

Shylock's speech has always given me a lot of trouble. My humanist, liberal upbringing makes me yearn for the second reading. I long, in this viciously othering play, for a moment that strikes a pure note of fellowship, in which the self recognizes itself in the other, even for the briefest existential blip. On the other hand, my historicist

\footnotetext{
${ }^{12}$ I thank Linda Neiberg for noting the relevance of this passage to my ideas about the play.
} 
training - not to mention the rest of the play, or even the rest of the speech with its devolution to revenge, or Solanio's callous response inclines me toward the first reading. Where in Renaissance religious thought do we find an unadulterated sense of common humanity that transcends religious boundaries - or for that matter, national, cultural, racial, or sexual ones? Yet it seems to me that most of Shakespeare's plays, particularly the tragedies, take the possibility of a common humanity as their fundamental - though by definition tragic subject. If the dream of a humanity in which the other is recognized as a self is always collapsing in Shakespeare, at least it is a recognizable dream. I tend therefore to settle uneasily upon the third possibility, in which I try to hold both the cynicism of manipulation and the optimism of connection at once, as if struggling to hold together the like poles of two magnets. The logic of the speech, it seems to me, is less mimetic - I'm like you or unlike you - as it is appetitive - I hunger and you hunger. We hunger for each other. Shylock does not reflect the Christians' sentience; he eats it, and the Christians are too busy doing the same to notice. Shylock and the Christians sit, for a moment, at the same table, eating the same foods and imbibing the same edifying lessons. Unfortunately, the chief lesson absorbed by both Jew and Christian is neither hospitality nor civility, as it would be at a proper humanist feast, but savagery - an eye for an eye, pound for pound. The food at this feast is not humanism but humans. ${ }^{13}$

To focus on eating in the passage hardly absolves me of the struggle to understand its tensions. Yet eating does occur in the passage an awful lot, to the extent of becoming practically a master trope. "To bait fish withal" - "If it will feed nothing else, it will feed my revenge" - "fed with the same food" - "if you poison us do we not die," as well as related terms like "organs" and "senses." The "resemblance" that Shylock describes is played out, for better and worse, largely through what we might call a gastronomic imagination, even a gastronomic ethics. Eating connects people, even when that eating is entrapping, or poisonous, or feeds nothing more, nor less, than the bile of revenge. Why? What is eating's "instruction"?

13 On the civilizing process of the humanist meal, see Michel Jeanneret, A Feast of Words: Banquet and Table Talk in the Renaissance, Chicago and Cambridge, University of Chicago Press, 1991; Norbert Elias, The Civilizing Process, Oxford, B. Blackwell, 1978. 
Eating inevitably accomplishes two things that are, in their way, opposites. First, eating involves the destruction, via ingestion, of one creature by another. Second, eating contributes to the formation of community through acts of sharing and commensality. Humans are the only primates that share food while sitting around in a circle, exposing their teeth. The bio-archaeologist Martin Jones marvels over the fact that "at some point, our own ancestors turned those danger signals around and transformed them into the very essence of conviviality that defines humanity." 14 But in doing so, they did not leave the old way of eating behind. Eating is still a site of potential violence; we are still dangerous when we bare our teeth.

This observation lies at the core of the terrible and beautiful paradox of eating. Any individual act of eating of necessity divides and destroys, even as it nourishes. But human eating has the potential to create - indeed can be the very essence of - the social bonding that produces the multifarious structures of human community and identity. In this passage and in The Merchant of Venice as a whole, we as readers or viewers must constantly negotiate between these two aspects of eating, the eating that destroys and the eating that unites. Often these two elements of eating occur simultaneously. Or rather, since they always occur simultaneously, Shakespeare has a way in this play of making their simultaneity absolutely present to our consciousness and to the "inner workings" of human relationships. In Shylock's speech, we encounter the push-pull of eating in a particularly intense way. Eating unites - we are all fed with the same food, we all hope to find in a shared meal the sense of community that humans make and crave. And eating destroys - we use food to bait fish so that we can eat those fish, and sometimes those fish are other people, and sometimes the bait is other people too. We make community and we destroy it, mouths exposed, bent on love and revenge. ${ }^{15}$

\footnotetext{
${ }^{14}$ Martin Jones, Feast: Why Humans Share Food, Oxford, Oxford University Press, 2007, p. 2.

${ }^{15}$ It is striking to consider in this context the theory that kissing-the opening of the mouth in love-may well have developed behaviorally from food-sharing. "Mouth-to-mouth sharing," writes Jones, "remains the predominant mode [of food-sharing] among mammals and birds.... In courtship, the actual transfer of food may have disappeared, and affection be communicated by the meeting of mouths alone. Ibid., p. 36 .
} 
$V$.

Horribly, in the trial scene, Shakespeare stages via metaphor the banquet he withheld in Act II. Antonio is "set forth," prepared for Shylock's knife, bare-chested and yet "covered" as a roast pig covers a table. Shylock describes Antonio as a "gaping pig," but Antonio turns himself kosher, referring to himself both as mutton and fruit. Gratiano calls Shylock a ravenous wolf. In her famous speech, Portia compares mercy to manna, and reminds Shylock that "mercy seasons justice." The duke, in kind, begs Shylock for "a dram of mercy." Shylock, like Titus, plays the double role of cook and carver, a preparer and opener of bodies. As Shylock demonstrates his obsessive desire to open Antonio, to show the devil within the "gaping pig," we feel the trap of the play close about him. Not only will he not get his vengeful wish, but he will unwittingly become the devil he insists he is not - or the devil becomes trapped inside him, banished there by the play's othering machine, to be drowned in the canals of Venice.

The Shylock who appears at the trial scene is a foregone conclusion, a cipher for ethically sanctioned violence. The Duke others Shylock as soon as he enters, calling him "A stony adversary, an inhuman wretch, / Uncapable of pity, void and empty / From any dram of mercy" (Iv.i.4-7). Shylock is radically empty - he has no interiority. He's been reduced, and has reduced himself, to nothing but the hunger of revenge. He is like the "blatant beast" in Book 5 of Spenser's Faerie Queene - the enemy of justice, composed of little more than a mouth and a stomach. The play's relative success at jettisoning Shylock while maintaining its comic genre depends on making sure that he is relegated to the position of absolute ethical other. Does revenge always take the form in Shakespeare, or in Renaissance drama, of hunger, and specifically of cannibalistic hunger?

The cannibalistic resonances of the trial scene - the pound of flesh equivalent to that of mutton or goat, Antonio as a "tainted wether" or a "gaping pig," the language of "seasoning," "sacrifice," and "manna" - have been noted, and indeed are impossible to ignore. ${ }^{16}$ But the crucial element by which Balthazar manipulates Shylock out of

${ }^{16}$ We might also note that the "pound of flesh," edible if not eaten, resonates with 2 Maccabees 7:3-5, in which a Jewish martyr is sautéed alive in a giant pan because he refuses to eat pork. See Goldstein, "The Price of Pork," for further discussion of the relevance of Maccabees. 
his bond has not been discussed in this context: the requirement that "no jot of blood" be shed. The obvious resonance - the proverbial bloodsucking usurer deprived of his chief form of sustenance - might have sounded familiar to a Renaissance audience. But blood also returns us, in a surprising way, to the kosher laws that introduce Shylock, and with which our discussion began.

The Bible strictly prohibits the eating of animal blood in Genesis 9:4: "But flesh with the life thereof, which is the blood thereof, shall ye not eat" (KJV). For the post-Talmudic rabbis, this law became one of the groups of strictures collectively known as the Noahide or Noahite laws, because they were delivered either to Adam and Eve, or to Noah on the occasion of God's covenant with him. Because the laws were given to Noah rather than Moses - because, that is, the laws preceded the creation of the Jewish people - they were thought to apply to all peoples, not just Jews, and thus to have the force of universal ethical obligation.

Although sixteenth-century Christians generally honored the laws, they did not consider the blood prohibition one of them. This posed a problem, however, because along with not giving food to idols, blood is the one food prohibition carried over from the Old Testament to the New. The prohibition is in fact repeated twice, in Acts 15:29"That ye abstain from meats offered to idols, and from blood, and from things strangled, and from fornication" - and in Acts 21:25. In the Renaissance, the theological question of whether Christians should abstain from blood-eating was by no means a settled one. In the 1596 Christian Exercise of Fasting, the Calvinist sabbatarian Henry Holland reasonably posed the radical question: "The Apostles commaunded to abstaine from bloud... What Christian observes that this day? and if some few do feare to touch such things, they are mocked of the rest." 17 Starting in Shakespeare's time, we find the blood prohibition, and the Noahide laws in general, significantly at issue in both theological and culinary approaches to questions of eating.

What are we to make of the fact that the turning point in Shylock's trial concerns not just murder but the shedding of a live animal's blood - "the tainted wether" of the Christian flock? An act

17 Quoted in Tristram Stuart, The Bloodless Revolution: a Cultural History of Vegetarianism from 1600 to Modern Times, New York, W. W. Norton \& Company, 2007, p. 106. 
expressly forbidden to Jews (as, needless to say, is the homicide), and problematic for Christians? Shylock does not, as far as we know, plan to drink the blood, but the scene's cannibalistic overtones, alongside the association of usurers with bloodsucking, makes the symbolic resonance unavoidable. Much has been made of the fact that Portia traps Shylock using the very words of his bond, but something more dramatic and theologically complex is going on here. Portia's checkmate of Shylock uses not only Venetian, but also Jewish law. If not explicit, the symbolic structure of Shylock's desire and Portia's rebuttal is nevertheless clear. Portia might be seen for this moment not just as a civil judge but as a Rabbinical one, presenting Shylock with his religious error - the error of a Jew who refuses, not Christian laws, but his own. Shylock's decision to dine with the Christians in order to feed upon them, thus reneging on his own professed dietary observance, comes back to haunt his final moments as a Jew. His failure to eat correctly in accepting Bassanio's invitation is repeated much more sensationally here, as his ignorance of more important prohibitions murder, cutting the flesh from a living animal, abstaining literally and metaphorically from the barbarity of blood - produces a failure of eating with (for Shylock) catastrophic consequences.

Such, at least, is one interpretation, and one that generally absolves Portia of ethical wrongdoing. But as with most analyses of the play, the message of this moment is considerably more ambiguous. If Shylock breaks several of the Noahide commandments, some literally and some symbolically, so do the Christians. Most strikingly, having denied Shylock the right to take blood from a living being, the Duke promptly repeats the crime. When he announces that the state and Antonio will divide his wealth, Shylock responds by echoing Genesis 9:4: "you take my life/ When you do take the means whereby I live" (Iv.i.397-98). For Shylock, to destroy his living is to drain the "vital spirits," as Calvin calls them, that reside in the blood, killing him while he is alive. Shylock's intended murder is literal while the Duke's appears metaphorical, but not from Shylock's point of view - he immediately reads the financial punishment as a physical one. Rather than a failure of the literalist Jewish imagination, Shylock's response seems to me to give the lie to the Duke's insistence on his own mercy. Meanwhile, Portia's response to this is to ask, "What mercy can you render him, Antonio?" In this context, the word "render," with its 
implication of rendering the fat from a cooked animal, is both apt and chilling. Shylock's goose is cooked, and his fat is his money; the Duke has rendered it. Now Antonio will proceed to remove the pound of spirit nearest the heart - his religion. ${ }^{18}$

Central to the Noahide laws is the establishment of a justice system. In a sense, it is the legal system of Venice itself that is on trial in this scene: how the audience feels about the scene depends largely upon whether we accept the legal outcome as fair. I cannot speak to the plausible range of Elizabethan reactions, but for most modern audiences, it is nearly impossible to do so. Enmeshed in the very questions that the Noahide laws seek to answer, the scene may be viewed as replaying the fundamental moment of communal Biblical ethics - the first point at which God gives laws to a community instead of individuals (such as Adam and Eve). Although God's covenant is made with Noah, it is framed in terms of community: God's promise never again to flood the earth is to remain in force long after Noah's death. The trial scene's consideration of these laws reminds us that the literal or metaphorical boundaries of the table are also those of the community, and that the rules that bind the commensals of the play create one community and vilify another.

In the end, the Christian containers remain intact, and apparently well-fed. Antonio retains his flesh as well as his ships, which arrive in port intact. Antonio's foreboding vision in the play's first scene, of the "dangerous rocks, / Which touching but my gentle vessel's side / Would scatter all her spices on the stream" (I.i.32-34), does not come to pass. But I wonder whether the trial, with its evocation of the Noahide laws, does not encourage us to remember another ship - the great Ur-ship of Judeo-Christian tradition, Noah's ark, with its precious living cargo. ${ }^{19}$ How far have we traveled from that ship, which finds safe passage through the agency of a dove, to the dish of cooked doves in Old Gobbo's basket in Act II, or to the bellies of Antonio's ships, heavy with inanimate goods? How far have we come from the

\footnotetext{
18 Needless to say, I am not in agreement with the supersessionists who view Shylock's conversion as a happy ending for that character. Every aspect of the trial scene is bent on humiliation and ruination. Conversion may be the millenarian goal for the Christians of the play, but this is not to be confused with the goal of the play itself. I take a skeptical view of the meaning of "mercy" in this scene, and my argument leads me to the conclusion that Shakespeare does too. See above, note p. 6.

${ }^{19}$ I am grateful to Dan Birkholz for pointing out the connection between the play and Noah's ark.
} 
project of rescuing animals to the project of rating humans as lower than animals? How far from the regeneration of the human species to the cutting loose of Belmont, that floating island, from the rest of the world? Noah's creaking ark haunts the trial scene, and indeed the whole play, with a silent admonishment of another ethics, one which here finds no safe harbor, neither Jewish nor Christian.

David B. Goldstein York University 